\title{
Anuran susceptibilities to ranaviruses: role of species identity, exposure route, and a novel virus isolate
}

\author{
Jason T. Hoverman ${ }^{1, *}$, Matthew J. Gray ${ }^{1}$, Debra L. Miller ${ }^{1,2}$ \\ ${ }^{1}$ Center for Wildlife Health, Department of Forestry, Wildlife and Fisheries, University of Tennessee, \\ 274 Ellington Plant Sciences Building, Knoxville, Tennessee 37996-4563, USA \\ ${ }^{2}$ Veterinary Diagnostic and Investigational Laboratory, College of Veterinary Medicine, University of Georgia, \\ 43 Brighton Road, Tifton, Georgia 31793, USA
}

\begin{abstract}
Ranaviruses are responsible for widespread amphibian die-offs, particularly with larval anurans. To understand the factors that may be contributing to the emergence of ranaviruses, we conducted 3 experiments that exposed 3 species of larval anurans to either endemic frog virus 3 (FV3) or an FV3-like isolate from a ranaculture facility. Our goals were to (1) determine the susceptibility of each species to each virus, (2) determine whether direct ingestion of virions or exposure to virions in a water bath were similarly lethal routes of transmission, and (3) quantify the effects of exposure duration on disease outcomes. We conducted our research in a controlled aquatic laboratory using a factorial combination of virus isolates, transmission routes, and exposure durations. While ranaviruses can affect many species, we found that larval anurans differ greatly in susceptibility to ranaviruses. Average mortality rates of Cope's gray tree frogs $(66 \%)$ and pickerel frogs $(68 \%)$ were similar but 3 -fold higher than for eastern narrow-mouthed toads. Direct ingestion of the viruses increased mean infection and mortality rates by $30 \%$ and caused death about 2 times faster compared to water bath exposure. However, exposure duration did not impact mean infection or mortality rates. We also found that the ranaculture isolate increased mortality by $>34 \%$ compared to FV3. Our results suggest that ranaviruses can rapidly infect and cause disease in multiple amphibian species. Given the risk associated with introducing novel ranaviruses from ranaculture facilities, we recommend that all nations adopt the protocol set forth by the World Organization for Animal Health for testing and certifying that amphibians that are commercially shipped are negative for ranavirus infection.
\end{abstract}

KEY WORDS: Emerging infectious disease - Pathogen pollution · Novel strain · Iridoviridae • Ranavirus · Frog virus $3 \cdot$ Anuran Resale or republication not permitted without written consent of the publisher

\section{INTRODUCTION}

The global emergence of infectious diseases in humans, livestock, wildlife, and plants has generated interest in understanding the factors that drive host-pathogen interactions (Daszak et al. 2000, Cleaveland et al. 2001, Dobson \& Foufopoulos 2001). Disease emergence may be driven by multiple factors, including differences in species susceptibility, transmission efficiency among hosts, and whether pathogens are novel or endemic (Dobson \& Foufopoulos 2001, McCallum et al. 2001, Cunningham et al. 2003).
By developing a mechanistic understanding of how these factors drive disease dynamics, we can predict outbreaks and potentially manage or reduce the negative consequences associated with disease (Keesing et al. 2006).

Among the classes of vertebrates, amphibians are considered the most imperiled (Stuart et al. 2004, Wake \& Vredenburg 2008). Emerging infectious diseases have been linked to amphibian declines (Daszak et al. 1999). In particular, ranaviruses are a group of amphibian pathogens that are globally distributed and have been linked to catastrophic mortality in larval 
and adult amphibians (Cunningham et al. 1996, 2007a,b, Jancovich et al. 1997, Bollinger et al. 1999, Petranka et al. 2003). In North America, the majority of reported ranavirus-associated mortality events among amphibians are due to ranaviruses acting alone or in combination with other factors (Green et al. 2002, Muths et al. 2006). For example, Green et al. (2002) documented that ranaviruses were the sole cause of 21 (48\%) reported amphibian mortality events in the United States. In addition to mortality events, field surveillance and laboratory studies have demonstrated that amphibians can be sublethally infected with ranaviruses (Brunner et al. 2004, Pearman et al. 2004, Gray et al. 2007, 2009a, Greer et al. 2008). While ranaviruses have been identified as the etiologic agent in mortality events of amphibians, research into the basic ecology of this pathogen and possible factors contributing to its emergence has been limited (Gray et al. 2009b).

Many pathogens are capable of infecting multiple host species, with varying degrees of virulence (Cleaveland et al. 2001, Parker \& Gilbert 2004); therefore, understanding the relative susceptibility of host species to a pathogen is fundamental to predicting host-pathogen dynamics (Dobson \& Foufopoulos 2001, Power \& Mitchell 2004). Most experiments addressing the effects of ranaviruses on amphibians have focused on a single amphibian species (e.g. Tweedell \& Granoff 1968, Jancovich et al. 2001, Pearman et al. 2004, Harp \& Petranka 2006, Majji et al. 2006). However, field surveillance studies (e.g. Greer et al. 2005, Gray et al. 2007) and reports of die-offs (e.g. Cunningham et al. 1996, Green et al. 2002) indicate that ranaviruses infect multiple hosts, and susceptibility likely differs among species. Schock et al. (2008) demonstrated that metamorphs of 4 amphibian species exhibited different mortality rates when exposed to ranaviruses. However, we are unaware of studies that have compared the relative susceptibility of multiple species of larval anurans.

One of the fundamental processes in infectious disease ecology is pathogen transmission (McCallum et al. 2001). In order to understand host-pathogen dynamics, identifying the most efficient routes of transmission and the exposure duration necessary for infection is critical (Gray et al. 2009b). Transmission of ranaviruses has been studied rather extensively (Jancovich et al. 1997, Brunner et al. 2007, Greer et al. 2008). We know that amphibians can become infected with ranaviruses through direct ingestion of virions or by exposure to contaminated water (Harp \& Petranka 2006, Brunner et al. 2007). However, it remains unclear whether these transmission routes differ with respect to infection rate and pathogen virulence, particularly in anuran larvae. Pearman et al. (2004) demonstrated that Italian agile frog Rana latastei tadpoles that consumed ranavirus-infected tissues experienced greater mortality compared to tadpoles that were merely exposed to infected tissue in water. Although this study provides preliminary evidence that the most efficient route of transmission in tadpoles may be direct ingestion, it was performed with only one species. Further, it remains unclear whether one-time exposure to virions is as effective as continuous exposure for initiating infection and causing disease. Most laboratory studies have challenged amphibian larvae with ranaviruses for a short duration (e.g. Pearman et al. 2004, Pearman \& Garner 2005); however, exposure in the environment could be continuous especially during a die-off. Addressing these issues will provide important insights into the dynamics of viral transmission.

One of the hypothesized factors in the recent emergence of ranaviruses in amphibian populations is novel strain introduction (Cunningham et al. 2003). Amphibian culture facilities may be an important source of novel virus strains or species (Majji et al. 2006, Picco \& Collins 2008). Given that amphibian densities in culture facilities are generally high, theory predicts that pathogen virulence will evolve due to high transmission rates between hosts (Ewald 1994). If amphibians from these facilities are released or escape into the wild, they could introduce highly virulent pathogens into naïve populations. Empirical studies have shown that ranaviruses isolated from ranaculture facilities or bait shops can be more pathogenic than endemic strains (Majji et al. 2006, Storfer et al. 2007). Additional studies are needed that compare the relative susceptibility of amphibians between ranaculture and endemic strains to assess the threat of commercially transporting infected amphibians among states or nations.

In this study, we conducted 3 experiments that exposed tadpoles from 3 anuran species across 3 families to either an endemic ranavirus (frog virus 3, FV3) or an FV3-like isolate from a ranaculture facility. Tadpoles were exposed to the viruses via an oral dose (i.e. direct ingestion), a short-term bath exposure for $3 \mathrm{~d}$, or a long-term bath exposure for $21 \mathrm{~d}$. The objectives of our study were to (1) determine the susceptibility of the 3 anuran species to 2 ranaviruses, (2) compare the effects of transmission route on infection rates and mortality, and (3) compare the effects of exposure duration on disease dynamics.

\section{MATERIALS AND METHODS}

Ranavirus and anuran larvae. For our experiments, we used the type species for Ranavirus (FV3) and an FV3-like isolate (referred to hereafter as the ranacul- 
ture isolate) from a ranaculture facility in Georgia, USA. FV3 was a wild isolate originally obtained from Rana (Lithobates) pipiens in the 1960s (Granoff et al. 1965). It was initially acquired by Debra Miller from Gregory Chinchar at The University of Mississippi. The ranaculture isolate was obtained in 2006 from a tissue homogenate (liver and kidney) of a recently metamorphosed American bullfrog Lithobates catesbeianus that died during a massive mortality event $(>50 \%)$ inside a commercial ranaculture facility in Georgia (GenBank accession no. EF101698; Miller et al. 2007). Given the high density and constant supply of amphibian hosts, we hypothesized that the isolate may have evolved high virulence (Ewald 1994). Thus, the ranaculture isolate potentially represents a highly virulent isolate that could be introduced via interstate sale or transport of amphibians. FV3 was on the 4th passage since receiving from Gregory Chinchar; the ranaculture isolate was on the 3rd passage since its original isolation.

Both isolates were cultured at The University of Georgia Veterinary Diagnostic and Investigational Laboratory (VDIL) using a protocol modified from Pearman et al. (2004). To propagate the viruses, we seeded $75 \mathrm{~cm}^{2}$ tissue culture flasks with fathead minnow cells (FHM) in growth media, and incubated the flasks at $23^{\circ} \mathrm{C}$ without $\mathrm{CO}_{2}$. Growth media consisted of minimal essential media (MEM) with Earle's salts and $10 \%$ fetal bovine serum (FBS). When a complete monolayer had formed, the growth media was removed, the monolayer rinsed gently with MEM, and $1 \mathrm{ml}$ of the stock virus added. Following a $60 \mathrm{~min}$ incubation period at $23^{\circ} \mathrm{C}$, we added MEM without FBS, and incubated the flasks at $23^{\circ} \mathrm{C}$ without $\mathrm{CO}_{2}$. When we observed $>80$ to $90 \%$ cytopathic effect (CPE) in the flasks, the flasks were frozen at $-70^{\circ} \mathrm{C}$. Flasks were frozen and thawed 3 times, and the viral suspension from all of the flasks combined and aliquoted into $15 \mathrm{ml}$ centrifuge tubes as the stock virus and stored at $-70^{\circ} \mathrm{C}$ at the VDIL. An aliquot of the stock viral solution was titered to determine the number of plaque forming units (PFUs). Following titer determination, the viruses were sent overnight to the University of Tennessee and stored at $-70^{\circ} \mathrm{C}$ until used in the experiments.

We collected amphibian egg masses from natural populations of pickerel frog Lithobates palustris, Cope's gray tree frog Hyla chrysoscelis, and eastern narrow-mouthed toad Gastrophryne carolinensis in April, May and July 2008, respectively. We collected 10 pickerel frog and 3 gray tree frog egg masses from separate ponds at the Seven Islands Wildlife Refuge in Knox County, Tennessee, USA (35 $57^{\prime} 14.3^{\prime \prime} \mathrm{N}$, $83^{\circ} 4^{\prime} 31.66^{\prime \prime} \mathrm{W}$, and $35^{\circ} 57^{\prime} 1.41^{\prime \prime} \mathrm{N}, 83^{\circ} 41^{\prime} 41.36^{\prime \prime} \mathrm{W}$, respectively), and 10 narrow-mouthed toad egg masses from a private pond in Loudon County, Tennessee, USA ( $35^{\circ} 44^{\prime} 54.99^{\prime \prime} \mathrm{N}$, 84 $14^{\prime}$ 5.81" W). All egg masses were transported to the controlled aquatic laboratory at The University of Tennessee Joe Johnson Animal Research and Teaching Unit. After hatching, the tadpoles were fed ground TetraMin fish flakes (Tetra) ad libitum until used in the experiments. The eggs and tadpoles were reared at $23^{\circ} \mathrm{C}$ and a $12: 12 \mathrm{~h}$ day:night photoperiod (Relyea \& Werner 1999). To reduce the likelihood of contamination among species, the species were reared in covered aquaria in different portions of the laboratory, new gloves were used when handling each species, and all equipment was disinfected with $0.75 \%$ Nolvasan ${ }^{\circledR}(2 \%$ chlorhexidine diacetate, Fort Dodge Animal Health; Bryan et al. 2009) after use with each species.

The previous history of ranavirus infections in the gray tree frog and narrow-mouthed toad populations was unknown, yet we had detected ranavirus in green frog tadpoles in the pond from which the pickerel frog egg masses were collected. Thus, we screened a sample of tadpoles for each species to determine if they were exposed to ranavirus prior to the start of the experiment. We euthanized 10 randomly selected tadpoles per species and tested liver and kidney tissue from each individual for ranavirus using real-time PCR prior to the start of each experiment. While gray tree frogs and narrow-mouthed toads tested negative, $80 \%$ of the pickerel frog tadpoles were positive. While it is possible that vertical transmission occurred (Duffus et al. 2008), definitive evidence of vertical transmission of ranaviruses in amphibians is lacking (Gray et al. 2009b). Thus, we suspect environmental contamination of the pickerel frog egg masses was the most likely means of ranavirus exposure. To verify the identity of the pickerel frog virus, we performed conventional PCR following the protocol by Mao et al. (1997) and submitted the PCR product for sequencing to SeqWright (SeqWright). The resulting 511 bp sequence (GenBank accession no. GU394000) had $99 \%$ identity with the FV3 major capsid protein (MCP) gene (GenBank accession no. FJ459783.1). We proceeded with the experiment with the caveat that experimental challenges (described hereafter) did not represent a first time exposure to the pathogen for this species.

Experimental design and analyses. The experiment was conducted for each of the 3 species when the tadpoles reached Gosner (1960) stage 30, which is the middle of pre-metamorphosis development (Altig \& McDiarmid 1999). We standardized the development stage because tadpole immunity has been shown to increase from embryonic stages through tadpole prometamorphosis in Xenopus laevis (Rollins-Smith 1998). Consequently, it would be expected that 
susceptibility to ranaviruses changes as tadpoles develop (Tweedell \& Granoff 1968). All experiments were conducted under identical laboratory conditions $\left(23^{\circ} \mathrm{C}\right.$ and a $12: 12 \mathrm{~h}$ day:night photoperiod), because water temperature and possibly photoperiod can influence susceptibility to ranaviruses (Rojas et al. 2005, Gray et al. 2007).

Our experimental units were 21 plastic tubs filled with $1 \mathrm{l}$ of water placed on $4 \times 8 \mathrm{ft}(\sim 1.2 \times 2.4 \mathrm{~m})$ shelving units at uniform height. The water was passed through a dechlorination filter and aged for at least $24 \mathrm{~h}$ in $700 \mathrm{l}$ tanks prior to use. A single tadpole was randomly selected from the original collection of egg masses and randomly assigned to an experimental unit. Each experiment consisted of 7 treatments with 20 replicate tadpoles per treatment, totaling 140 experimental units for each of the 3 species. The treatments were virus-free control, and oral, $3 \mathrm{~d}$ bath or $21 \mathrm{~d}$ bath exposure to FV3 or the ranaculture isolate. Tadpoles assigned to the oralexposure treatments were orally inoculated with $10^{6}$ PFUs of the appropriate virus isolate suspended in $10 \mu \mathrm{l}$ of Eagle's MEM. Oral inoculations were performed with a $20 \mu \mathrm{l}$ Fisherbrand single-channel pipetter (Fisher Scientific) equipped with a filter tip. To perform the oral inoculation, the tadpole was held with the oral disc facing up and the tip of the pipetter was slowly inserted into the oral disc. The inoculum was then slowly dispensed into the oral cavity. Based on previous studies, doses between $10^{2}$ and $10^{6}$ PFUs of the virus are sufficient to induce sublethal effects or morbidity in tadpoles (Tweedell \& Granoff 1968, Pearman et al. 2004, Pearman \& Garner 2005, Morales \& Robert 2007). We added $10^{6}$ PFUs of the appropriate virus isolate suspended in $10 \mu \mathrm{l}$ of MEM to each tub for the bath exposure treatments. Tadpoles were exposed to the virus for $3 \mathrm{~d}$ for the single exposure treatment, which has been shown to induce lethal infections in anuran larvae (Duffus et al. 2008). For the continuous treatment, $10^{6}$ PFUs of virus were added after each water change every $3 \mathrm{~d}$ (described below). To standardize exposure between treatments, tadpoles in control and bath treatments were orally inoculated with $10 \mu \mathrm{l}$ of MEM, $10 \mu \mathrm{l}$ of MEM were added to tubs of control and orally inoculated tadpoles, and $10 \mu \mathrm{l}$ of MEM were added to oral and $3 \mathrm{~d}$ bath treatments following each water change.

During the experiments, water was changed every $3 \mathrm{~d}$ to maintain water quality (Relyea 2004, 2005). To reduce the likelihood of contamination during the experiment, control larvae were handled first, followed by $3 \mathrm{~d}$ bath-exposed, continuous bath-exposed, and then orally exposed larvae. We also used new nets, changed gloves and rinsed all surfaces with $0.75 \%$
Nolvasan ${ }^{\circledR}$ between all virus treatments to prevent cross contamination. After each water change, tadpoles were fed a single $3 \mathrm{~d}$ ration of ground TetraMin based on $12 \%$ of body mass per day (Relyea 2002). The food ration was adjusted for changes in mass during the experiments using an additional sample of 20 tadpoles that were independent of the experiment but treated identically to the control treatment. These tadpoles were weighed every $3 \mathrm{~d}$ and their mean mass used to calculate the food ration. We did not weigh experimental tadpoles because we did not want to potentially introduce stress associated with the weighing process.

Experimental tadpoles were monitored daily for survival, morbidity, and gross signs of ranaviral disease (e.g. Jancovich et al. 1997, Converse \& Green 2005, Gray et al. 2009b). Dead tadpoles were removed from their containers, liver and kidney sections removed, and tissues frozen at $-70^{\circ} \mathrm{C}$. During necropsy, we noted gross signs associated with organs that were indicative of ranaviral disease (e.g. Gantress et al. 2003, Converse \& Green 2005, Miller et al. 2007, Gray et al. 2009b). The liver and kidney samples for each individual were pooled into a single microcentrifuge tube. We extracted the liver and kidney because these organs are known sites of virus infection (Tweedell \& Granoff 1968, Gantress et al. 2003, Converse \& Green 2005, Miller et al. 2007). The experiments were terminated after $21 \mathrm{~d}$, which is sufficient time for infection and morbidity to occur (Pearman et al. 2004, Pearman \& Garner 2005, Brunner et al. 2007). Live tadpoles remaining at the end of the experiments were euthanized by immersion in benzocaine hydrochloride and the same post-mortem procedures followed.

For ranavirus testing, we extracted DNA from the pooled liver and kidney sample for each individual using a DNeasy Blood and Tissue Kit (Qiagen). We used the Qubit ${ }^{\mathrm{TM}}$ fluorometer and the Quant-iT ${ }^{\mathrm{TM}}$ dsDNA BR Assay Kit (Invitrogen) to quantify the concentration of genomic DNA in the samples, which was used to quantify viral load using real-time PCR (qPCR; Yuan et al. 2006). We used the methods of Picco et al. (2007) for qPCR analysis. In brief, the PCR mixture included $12.5 \mu$ l of TaqMan ${ }^{\circledR}$ Universal PCR Master Mix (Applied Biosystems), $1.5 \mu \mathrm{l}$ of each primer at $10 \mathrm{pmol} \mu^{-1}$ (rtMCP-F [5'-ACA CCA CCG CCC AAA AGT AC-3'] and rtMCP-R [5'-CCG TTC ATG ATG CGG ATA ATG-3']), and $0.15 \mu \mathrm{l}$ of rtMCP-probe (5'CCT CAT CGT TCT GGC CAT CAA CCA-3'). Based on the values obtained from the Qubit $^{\mathrm{TM}}$ fluorometer, we added $1 \mu \mathrm{g}$ of template DNA and DNA grade water to a final volume of $25 \mu \mathrm{l}$. The qPCR was performed using a SmartCycler system (Cepheid). In each qPCR run, 3 controls were tested including a negative tadpole sample, a negative water sample, and an FV3- 
positive sample. In a separate $\mathrm{qPCR}$, we ran a concentration gradient for FV3 and the ranaculture isolate, which was used to calculate viral load (Yuan et al. 2006). We note that the relationships between viral load and species susceptibility or the state of ranaviral disease are currently unknown (Gray et al. 2009b), thus we caution readers about making such generalizations from these results.

The response variables for each experiment included survival, virus prevalence, and viral load. We tested for differences in daily survival curves among treatments using Wilcoxon-Gehan D test (Pyke \& Thompson 1986). We used Pearson's chisquare test $\left(\chi^{2}\right)$ to test for differences in survival at the end of the experiment (hereafter final survival) and virus prevalence among treatments (Zar 2009). The chi-square test assumes that the expected counts in the contingency tables are $>5$ and there are no empty cells (i.e. 0 counts). While this assumption was satisfied for the pickerel frog and Cope's gray tree frog data, this was not the case for the narrowmouthed toad data (Zar 2009). Therefore, we used Fisher's exact test to test for differences among treatments for the narrow-mouthed toads. We conducted a one-way ANOVA to test for differences in viral load $\left(\log _{10}\right.$-transformed) among treatments (Zar 2009). For this ANOVA, some treatments (e.g. controls) had no infected individuals, resulting in a mean and $\mathrm{SD}=0$. In these cases, these treatments were removed from the ANOVA, because biased test results could have occurred (Zar 2009). When main effect tests were significant, Bonferroni-corrected pairwise tests were performed for chi-square tests, and Tukey's honestly significant difference test was used to detect differences between means for ANOVAs (Zar 2009). For each species, we also used logistic analysis to determine the likelihood that an infected individual died. All analyses were conducted using SPSS 16.0 at $\alpha=0.05$.

\section{RESULTS}

Daily and final survival of narrow-mouthed toad tadpoles was not different among treatments (WilcoxonGehan $\mathrm{D}_{6}=4.7, \mathrm{p}=0.579$; Fisher's exact test $\mathrm{p}=0.62$; Figs. $1 \& 2$ ). From the narrow-mouthed toad tadpoles that were orally inoculated with FV3 and the ranaculture isolate, 15 and $35 \%$, respectively, became infected; however, the water bath exposure did not result in infection (Fisher's exact test $\mathrm{p}<0.001$; Fig. 2). Mean viral load of infected tadpoles did not differ between the FV3 and ranaculture isolate for this species $\left(F_{1,8}=2.6, p=0.145\right.$; Fig. 3$)$. Infected individuals were 3.8 -fold more likely to die than uninfected indi- viduals (Wald $\chi^{2}{ }_{1}=4.0, \mathrm{p}=0.045$ ). Mild to moderate edema of the body was the only gross sign of infection. Edema was noted in 15 and $10 \%$ of the tadpoles in the FV3 oral and $21 \mathrm{~d}$ bath exposure treatments, respectively, and $5 \%$ of the tadpoles in each of the ranaculture isolate treatments.

Compared to the control treatment, all virus treatments significantly reduced the daily survival of Cope's gray tree frog tadpoles, but the magnitude of the effect varied among treatments $\left(D_{6}=55.3, p<\right.$ 0.001; Fig. 1). Infection rate and mortality were greater in the oral-exposure treatment for both isolates and in the bath-exposure treatments for the ranaculture isolate compared to the remaining treatments $\left(\chi_{6}^{2}>55.7\right.$, $\mathrm{p}<0.001$; Fig. 2). Mortality was observed after 3 and $7 \mathrm{~d}$ following oral exposure of the ranaculture and FV3 isolate, respectively (Fig. 1). Within each isolatetreatment group, mortality and infection rate did not differ between the $3 \mathrm{~d}$ and $21 \mathrm{~d}$ bath exposure treatments (Fig. 2). Viral load of the infected individuals was similar across treatments $\left(F_{5,89}=1.7, \mathrm{p}=0.15\right.$; Fig. 3). Infected individuals were 172 -fold more likely to die than uninfected individuals (Wald $\chi^{2}{ }_{1}=24.3, \mathrm{p}<$ 0.001). Of the tadpoles that died during the experiment, the most common sign of disease $(65 \%$ of individuals) was moderate to severe edema of the body and hindlimbs. Erythema and hemorrhaging (55\% of individuals) were also observed on the body, hindlimbs, or around the oral disc. During necropsy, we observed pale livers and kidneys in $38 \%$ of the tadpoles.

Despite pre-exposure to an FV3-like ranavirus in the wild, daily survival of pickerel frog tadpoles was negatively affected by the virus treatments and followed similar trends to Cope's gray tree frog tadpoles $\left(\mathrm{D}_{6}=82.2, \mathrm{p}<0.001\right.$, Fig. 1$)$. Infection rate and mortality were greater in the oral-exposure treatment of both isolates and in the bath-exposure treatments for the ranaculture isolate compared to the remaining treatments $\left(\chi_{6}^{2}>55.7, \mathrm{p}<0.001\right.$; Fig. 2). Mortality was observed after 2 and $6 \mathrm{~d}$ following oral exposure of the ranaculture and FV3 isolate, respectively (Fig. 1). Within each isolate-treatment group, mortality and infection rate did not differ between the $3 \mathrm{~d}$ and $21 \mathrm{~d}$ bath treatments (Fig. 2). Viral load was greatest in the treatments with the largest infection and mortality rates and about double the mean levels observed in Cope's gray tree frog tadpoles for these treatments $\left(F_{6,79}=4.2, \mathrm{p}=0.001\right.$; Fig. 3$)$. Infected individuals were 34.1-fold more likely to die than uninfected individuals (Wald $\chi_{1}^{2}=50.8, \mathrm{p}<0.001$ ). Of the tadpoles that died during the experiment, $3 \%$ exhibited erythema of the body or hindlimbs, $12 \%$ showed moderate to severe edema of the body, and $69 \%$ had pale livers and kidneys. 

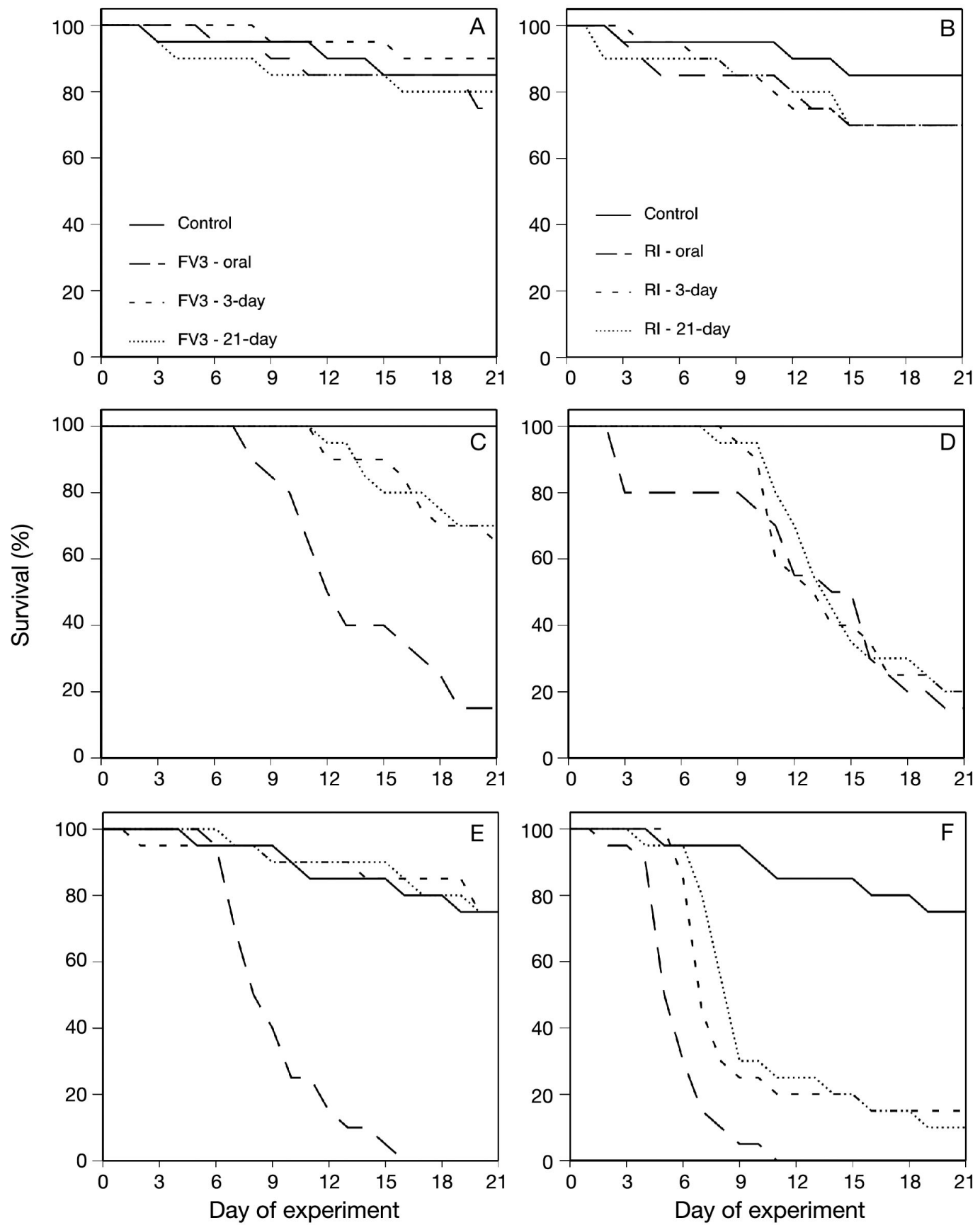

Fig. 1. Survival curves for (A,B) eastern narrow-mouthed toad Gastrophryne carolinensis, (C,D) Cope's gray tree frog Hyla chrysoscelis, and $(\mathrm{E}, \mathrm{F})$ pickerel frog Lithobates palustris tadpoles exposed to 7 ranavirus treatments. Tadpoles were exposed to either frog virus 3 (FV3) (A, C, E) or an FV3-like isolate (RI) (B, D, F) from a ranaculture facility in Georgia, USA. Treatments: exposures to the virus isolates $\left(10^{6}\right.$ plaque forming units) via oral inoculation (oral), short-term $3 \mathrm{~d}$ bath exposure (3-day), or longterm $21 \mathrm{~d}$ bath exposure (21-day); control treatment for each species displayed for comparison. Per treatment: $\mathrm{n}=20$ tadpoles

\section{DISCUSSION}

Our results indicate that susceptibilities to ranavirus differ among larval anuran species. Across all virus treatments, mortality rates of Cope's gray tree frog
(66\%) and pickerel frogs (68\%) were similar but 3-fold higher than for eastern narrow-mouthed toads. All virus treatments caused infection in Cope's gray tree frog and pickerel frog tadpoles: prevalence across treatments was $80 \%$ and $65 \%$, respectively. In con- 

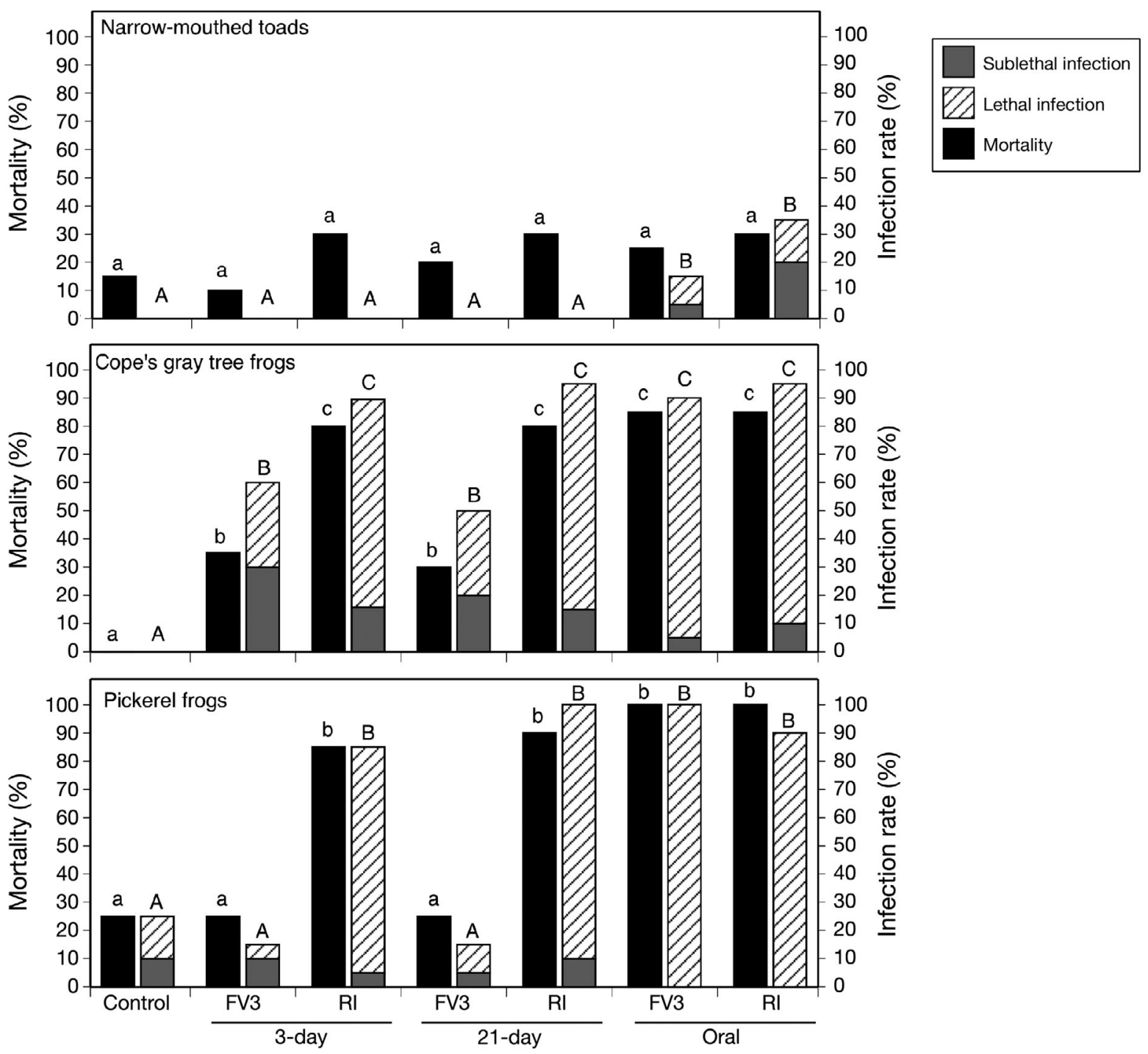

Fig. 2. Final mortality and infection rate at the end of the experiment for eastern narrow-mouthed toad Gastrophryne carolinensis, Cope's gray tree frog Hyla chrysoscelis, and pickerel frog Lithobates palustris tadpoles exposed to 7 ranavirus treatments (see Fig. 1 for a description of the virus treatments). Infection rate is divided into number of infected individuals that survived until the end of the experiment (sublethal infection) and those that died during the experiment (lethal infection). Treatments sharing lowercase and uppercase letters are not statistically different $(\mathrm{p}>0.05)$. Per treatment: $\mathrm{n}=20$ tadpoles

trast, narrow-mouthed toads only became infected $(25 \%)$ in oral-exposure treatments. Species-specific differences in susceptibility to ranaviruses have been reported for juvenile amphibians (Schock et al. 2008). The mechanisms responsible for species-specific trends in susceptibility remain unclear, but may be related to the probability of viral exposure over evolutionary time. For example, species exposed less often historically to ranaviruses due to life history (e.g. those residing in ephemeral wetlands) may have less sophisticated innate and adaptive immune responses to ranaviruses. The observation of recurrent ranavirusassociated die-offs of wood frogs Lithobates sylvaticus, which is an ephemeral-pond breeder, supports this hypothesis (Green et al. 2002, Petranka et al. 2003, Greer et al. 2005, Duffus et al. 2008). However, if this prediction was entirely true, narrow-mouthed toads should have been the most susceptible species in our experiment given they are known to use ephemeral wetlands (Dodd 2004). Further, mean viral load in pickerel frogs was 2-fold higher than in Cope's gray tree frogs, suggesting higher susceptibility of pickerel frogs, but this species often inhabits more permanent wetlands than gray tree frogs (Harding 1997). The higher viral load in the pickerel frogs may have been a consequence of their exposure to an FV3-like ranavirus prior to the start of the experiment. These results suggest that differences in species susceptibil- 


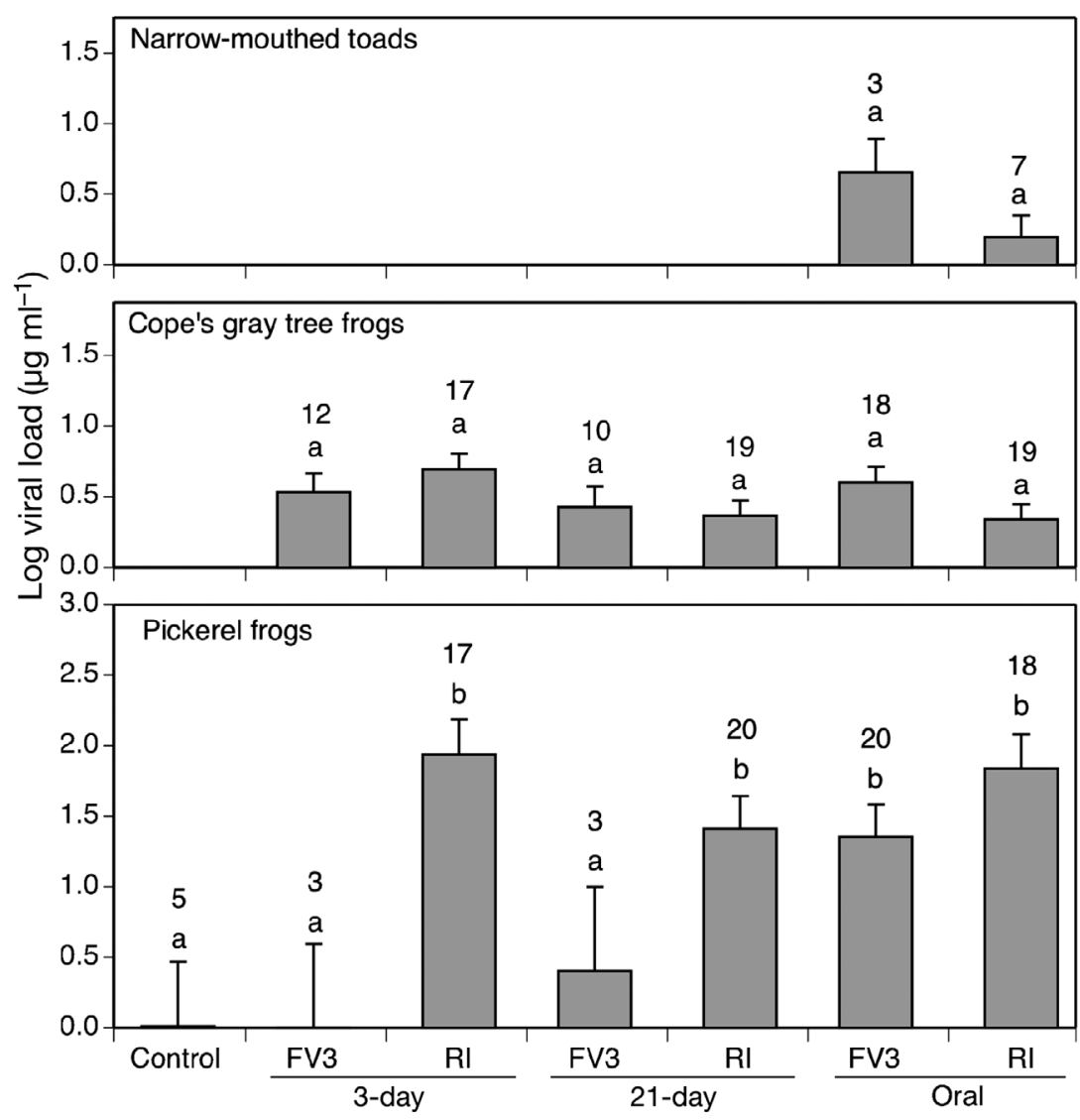

Fig. 3. Viral load of infected eastern narrow-mouthed toad Gastrophryne carolinensis, Cope's gray tree frog Hyla chrysoscelis, and pickerel frog Lithobates palustris tadpoles exposed to 7 ranavirus treatments (see Fig. 1 for a description of the virus treatments). Data are means + SE. Real-time PCR was used to quantify viral load. Treatments sharing lowercase letters are not statistically different $(p>0.05)$. Numbers above each bar = sample size

ity to ranaviruses probably are not entirely dependent on habitat associations or evolutionary exposure.

Pickerel frogs were infected with an FV3-like ranavirus from their natal habitat prior to the start of our experiment. The high infection and mortality rates of the pickerel frogs suggest that prior exposure to a ranavirus does not necessarily confer greater resistance to infections by other strains or isolates (i.e. no cross protection). Previous work has demonstrated that amphibians induce an adaptive immune response to repeated exposures to ranaviruses (e.g. anti-FV3 antibody response of the IgY isotype; Gantress et al. 2003, Maniero et al. 2006). Indeed, some adult and larval amphibians are resistant to second or third exposures to ranaviruses following an initial FV3 infection ( $\mathrm{Zu}-$ panovic et al. 1998, Gantress et al. 2003, Majji et al. 2006, Maniero et al. 2006). These results are contrary to our findings; however, it is possible that the early development stage of our larvae (Gosner 30) was a factor. Although our experiment was not designed to test the role of the adaptive immune response in conferring resistance to ranaviruses, our results suggest that future experiments that compare the function of the adaptive immune system across species and at various development stages will be valuable to understanding differences in susceptibility, especially to endemic versus novel ranaviruses.

We found that direct ingestion of virus tended to be more virulent than exposure to virions encountered in a water bath. Mean infection and mortality rates were 63 and $55 \%$, respectively, for bath exposure treatments compared to 93 and $90 \%$ for oral inoculations in pickerel and gray tree frog tadpoles. Moreover, first mortality occurred on average 4.5 and $8 \mathrm{~d}$ following oral inoculation and initial bath exposure, respectively. Also, narrow-mouthed toad tadpoles only became infected when orally inoculated with the virus. Our results support previous findings that direct ingestion of virions is the most lethal route of transmission for anuran larvae. Pearman et al. (2004) found that Rana latastei tadpoles that cannibalized virus-infected carcasses experienced $30 \%$ greater mortality compared to tadpoles that were exposed to virions in a water bath. Our results also support previous findings that ingestion of virions can result in rapid mortality (Pearman et al. 2004, Harp \& Petranka 2006). Rapid progression of disease is likely related to rapid cell infection and viral replication when infectious virions are ingested. Brunner et al. (2005) estimated that the doubling rate of ranaviruses in a salamander host was 0.7 to $1.8 \mathrm{~d}$, and cell death can occur as quickly as a few hours following infection (Williams et al. 2005). Rapid virus replication likely explains the lack of a significant difference in mortality rate and viral load between the bath exposure treatments. A single $3 \mathrm{~d}$ exposure to the virus was sufficient to initiate infection and progression to disease in pickerel and Cope's gray tree frog tadpoles. While previous studies have used 1 to 7 d exposures to infect larval amphibians (Pearman et al. 2004, Pearman \& Garner 2005, Brunner et al. 2007, Duffus et al. 2008), it also has been shown that $1 \mathrm{~s}$ of physical contact between an infected and uninfected salamander is sufficient to initiate infection (Brunner et al. 2007). Together, these results suggest that ranaviruses can infect and cause disease quickly in susceptible larval anurans. 
We found that an FV3-like isolate obtained from American bullfrogs in a ranaculture facility in Georgia, USA, was generally more lethal than FV3. Mean infection and mortality rates were 54 and $50 \%$, respectively, for FV3 compared to 91 and $84 \%$ for the ranaculture isolate in pickerel and Cope's gray tree frog tadpoles. For infected individuals of these species, first mortality occurred on average 4 and $8 \mathrm{~d}$ following exposure to the ranaculture and FV3 isolate, respectively. The greater virulence associated with the ranaculture isolate compared to FV3 may be the consequence of laboratory attenuation of FV3, which has been reared in cell culture for over $50 \mathrm{yr}$ (Chinchar et al. 2009). However, our results support previous findings that ranaviruses associated with ranaculture facilities or bait shops are more virulent than endemic strains. Majji et al. (2006) reported greater mortality for American bullfrog tadpoles exposed to Rana catesbeiana virus $\mathrm{Z}(\mathrm{RCV}-\mathrm{Z})$ isolated from a ranaculture facility compared to tadpoles exposed to FV3. Storfer et al. (2007) provided molecular evidence that ranaviruses were emerging in some populations of tiger salamanders Ambystoma tigrinum due to interstate transport of bait salamanders infected with novel strains. On the global scale, Schloegel et al. (2009) documented 8.5 and $62 \%$ infection prevalence of ranaviruses and Batrachochytrium dendrobatidis, respectively, in American bullfrogs Lithobates catesbeianus imported into 3 United States ports from culture facilities. Together, these results provide evidence that amphibian culture facilities can be significant sources of virulent pathogens and provide justification for conservation strategies that attempt to reduce the likelihood of pathogen pollution.

Our study provides additional evidence that ranaviruses infect multiple hosts, with susceptibility to the same isolates differing among amphibian species. Additional research relating susceptibility to evolutionary and environmental factors will be fundamental to identifying drivers of disease emergence in amphibians and mitigating the likelihood of emergence. Our results also support previous findings that ranaviruses can quickly cause mortality in tadpoles, especially if virions are ingested directly. Given that tadpoles scavenge infected carcasses naturally (Harp \& Petranka 2006), it is not surprising that ranaviral disease can spread fast in wild anuran populations. Such rapid mortality rates underscore the need for frequent surveillance of ranaviral disease in wild populations to increase the likelihood that die-offs are documented (Gray et al. 2009b). Our results also indicate that ranaviruses associated with ranaculture facilities can be more virulent than wild strains. As suggested by previous studies (Schloegel et al. 2009), we recommend that nations follow the World Organization for
Animal Health (OIE) guidelines to test and certify that amphibians shipped commercially are absent of ranaviruses because of the risk associated with introducing novel ranaviruses into native populations. Moreover, within national borders, nations should consider regulations that prevent the shipment of amphibians among ranaculture facilities and watersheds without certifying that the amphibians are absent of ranaviruses (Gray et al. 2009b).

Acknowledgements. We thank the University of Tennessee Institute of Agriculture and Tennessee Wildlife Resources Agency (TWRA) for funding this study. The University of Georgia Veterinary Diagnostic and Investigational Laboratory in Tifton, Georgia, for logistical support; we especially thank C. Baldwin for providing the virus isolates and L. Whittington for conducting the real-time PCR. We also thank D. Gaillard, N. Haislip, and B. Thompson for providing assistance with the experiments. A. Cunningham and several anonymous reviewers provided many helpful comments on the manuscript. All animal husbandry and euthanasia procedures followed an approved University of Tennessee IACUC protocol (\#1755). Collection of egg masses was approved by the TWRA (Scientific Collection Permit \#1990).

\section{LITERATURE CITED}

Altig R, McDiarmid RW (1999) Body plan: development and morphology. In: McDiarmid RW, Altig R (eds) Tadpoles: the biology of anuran larvae. University of Chicago Press, Chicago, IL, p 24-51

Bollinger TK, Mao JH, Schock D, Brigham RM, Chinchar VG (1999) Pathology, isolation, and preliminary molecular characterization of a novel iridovirus from tiger salamanders in Saskatchewan. J Wildl Dis 35:413-429

> Brunner JL, Schock DM, Davidson EW, Collins JP (2004) Intraspecific reservoirs: complex life history and the persistence of a lethal ranavirus. Ecology 85:560-566

Brunner JL, Richards K, Collins JP (2005) Dose and host characteristics influence virulence of ranavirus infections. Oecologia 144:399-406

Brunner JL, Schock DM, Collins JP (2007) Transmission dynamics of the amphibian ranavirus Ambystoma tigrinum virus. Dis Aquat Org 77:87-95

$>$ Bryan L, Baldwin CA, Gray MJ, Miller DL (2009) Efficacy of select disinfectants at inactivating Ranavirus. Dis Aquat Org 84:89-94

Chinchar VG, Hyatt AD, Miyazaki T, Williams T (2009) Family Iridoviridae: poor viral relations no longer. Cur Top Microbiol Immunol 328:123-170

> Cleaveland S, Laurenson MK, Taylor LH (2001) Diseases of humans and their domestic mammals: pathogen characteristics, host range and the risk of emergence. Philos Trans R Soc Lond B Biol Sci 356:991-999

Converse KA, Green DE (2005) Diseases of tadpoles. In: Majumdar SK, Huffman JE, Brenner FJ, Panah AI (eds) Wildlife diseases: landscape epidemiology, spatial distribution and utilization of remote sensing technology. The Pennsylvania Academy of Science, Easton, PA, p 72-88

> Cunningham AA, Langton TES, Bennett PM, Lewin JF, Drury SEN, Gough RE, MacGregor SK (1996) Pathological and microbiological findings from incidents of unusual mortality of the common frog (Rana temporaria). Philos Trans R 
Soc Lond B Biol Sci 351:1539-1557

Cunningham AA, Daszak P, Rodriguez JP (2003) Pathogen pollution: defining a parasitological threat to biodiversity conservation. J Parasitol 89(Suppl):S78-S83

> Cunningham AA, Hyatt AD, Russell P, Bennett PM (2007a) Emerging epidemic diseases of frogs in Britain are dependent on the source of ranavirus agent and the route of exposure. Epidemiol Infect 135:1200-1212

Cunningham AA, Hyatt AD, Russell P, Bennett PM (2007b) Experimental transmission of a ranavirus disease of common toads (Bufo bufo) to common frogs (Rana temporaria). Epidemiol Infect 135:1213-1216

Daszak P, Berger L, Cunningham AA, Hyatt AD, Green DE, Speare R (1999) Emerging infectious diseases and amphibian population declines. Emerg Infect Dis 5: 735-748

Daszak P, Cunningham AA, Hyatt AD (2000) Wildlife ecology. Emerging infectious diseases of wildlife: threats to biodiversity and human health. Science 287:443-449

Dobson A, Foufopoulos J (2001) Emerging infectious pathogens of wildlife. Philos Trans R Soc Lond B Biol Sci 356: 1001-1012

Dodd CK (2004) The amphibians of Great Smoky Mountains National Park. University of Tennessee Press, Knoxville, TN

Duffus ALJ, Pauli BD, Wozney K, Brunetti CR, Berrill M (2008) Frog virus 3-like infections in aquatic amphibian communities. J Wildl Dis 44:109-120

Ewald PW (1994) Evolution of infectious diseases. Oxford University Press, New York

> Gantress J, Maniero GD, Cohen N, Robert J (2003) Development and characterization of a model system to study amphibian immune responses to iridoviruses. Virology 311:254-262

Gosner KL (1960) A simplified table for staging anuran embryos and larvae with notes and identification. Herpetologica 16:183-190

Granoff A, Came PE, Rafferty KA (1965) The isolation and properties of viruses from Rana pipiens: their possible relationship to the renal adenocarcinoma of the leopard frog. Ann NY Acad Sci 126:237-255

Gray MJ, Miller DL, Schmutzer AC, Baldwin CA (2007) Frog virus 3 prevalence in tadpole populations inhabiting cattle-access and non-access wetlands in Tennessee, USA. Dis Aquat Org 77:97-103

Gray MJ, Miller DL, Hoverman JT (2009a) First report of Ranavirus infecting lungless salamanders. Herpetol Rev 40:316-319

Gray MJ, Miller DL, Hoverman JT (2009b) Ecology and pathology of amphibian ranaviruses. Dis Aquat Org 87: 243-266

Green DE, Converse KA, Schrader AK (2002) Epizootiology of sixty-four amphibian morbidity and mortality events in the USA, 1996-2001. Ann NY Acad Sci 969:323-339

> Greer AL, Berrill M, Wilson PJ (2005) Five amphibian mortality events associated with ranavirus infection in south central Ontario, Canada. Dis Aquat Org 67:9-14

Greer AL, Briggs CJ, Collins JP (2008) Testing a key assumption of host-pathogen theory: density and disease transmission. Oikos 117:1667-1673

Harding JH (1997) Amphibians and reptiles of the Great Lakes region. University of Michigan Press, Ann Arbor, MI

> Harp EM, Petranka JW (2006) Ranavirus in wood frogs (Rana sylvatica): potential sources of transmission within and between ponds. J Wildl Dis 42:307-318

Jancovich JK, Davidson EW, Morado JF, Jacobs BL, Collins JP
(1997) Isolation of a lethal virus from the endangered tiger salamander Ambystoma tigrinum stebbinsi. Dis Aquat Org 31:161-167

> Jancovich JK, Davidson EW, Seiler A, Jacobs BL, Collins JP (2001) Transmission of the Ambystoma tigrinum virus to alternative hosts. Dis Aquat Org 46:159-163

Keesing F, Holt RD, Ostfeld RS (2006) Effects of species diversity on disease risk. Ecol Lett 9:485-498

Majji S, LaPatra S, Long SM, Sample R, Bryan L, Sinning A, Chinchar VG (2006) Rana catesbeiana virus Z (RCV-Z): a novel pathogenic ranavirus. Dis Aquat Org 73:1-11

- Maniero GD, Morales H, Gantress J, Robert J (2006) Generation of a long-lasting, protective, and neutralizing antibody response to the ranavirus FV3 by the frog Xenopus. Dev Comp Immunol 30:649-657

> Mao J, Hendrick RP, Chinchar VG (1997) Molecular characterization sequence analysis, and taxonomic position of newly isolated fish iridoviruses. Virology 229:212-220

McCallum H, Barlow N, Hone J (2001) How should pathogen transmission be modelled? Trends Ecol Evol 16:295-300

Miller DL, Rajeev S, Gray MJ, Baldwin CA (2007) Frog virus 3 infection, cultured American bullfrogs. Emerg Infect Dis 13:342-343

Morales HD, Robert J (2007) Characterization of primary and memory CD8 T-cell responses against ranavirus (FV3) in Xenopus laevis. J Virol 81:2240-2248

Muths E, Gallant AL, Campbell EHC, Battaglin WA and others (2006) The amphibian research and monitoring initiative (ARMI): 5 -year report. Scientific Investigations Report 2006-5224. US Geological Survey, US Dept. Interior

Parker IM, Gilbert GS (2004) The evolutionary ecology of novel plant-pathogen interactions. Annu Rev Ecol Evol Syst 35:675-700

> Pearman PB, Garner TWJ (2005) Susceptibility of Italian agile frog populations to an emerging strain of Ranavirus parallels population genetic diversity. Ecol Lett 8: 401-408

Pearman PB, Garner TWJ, Straub M, Greber UF (2004) Response of the Italian agile frog (Rana latastei) to a Ranavirus, Frog Virus 3: a model for viral emergence in naive populations. J Wildl Dis 40:660-669

Petranka JW, Murray SS, Kennedy CA (2003) Responses of amphibians to restoration of a southern Appalachian wetland: perturbations confound post-restoration assessment. Wetlands 23:278-290

> Picco AM, Collins JP (2008) Amphibian commerce as a likely source of pathogen pollution. Conserv Biol 22:1582-1589

> Picco AM, Brunner JL, Collins JP (2007) Susceptibility of the endangered California tiger salamander, Ambystoma californiense, to Ranavirus infection. J Wildl Dis 43: $286-290$

> Power AG, Mitchell CE (2004) Pathogen spillover in disease epidemics. Am Nat 164:S79-S89

> Pyke DA, Thompson JN (1986) Statistical analysis of survival and removal experiments. Ecology 67:240-245

Relyea RA (2002) Competitor-induced plasticity in tadpoles: consequences, cues, and connections to predator-induced plasticity. Ecol Monogr 72:523-540

Relyea RA (2004) Growth and survival of five amphibian species exposed to combinations of pesticides. Environ Toxicol Chem 23:1737-1742

Relyea RA (2005) The lethal impacts of roundup and predatory stress on six species of North American tadpoles. Arch Environ Contam Toxicol 48:351-357

Relyea RA, Werner EE (1999) Quantifying the relation between predator-induced behavior and growth performance in larval anurans. Ecology 80:2117-2124 
Rojas S, Richards K, Jancovich JK, Davidson EW (2005) Influence of temperature on Ranavirus infection in larval salamanders Ambystoma tigrinum. Dis Aquat Org 63:95-100

Rollins-Smith LA (1998) Metamorphosis and the amphibian immune system. Immunol Rev 166:221-230

Schloegel LM, Picco AM, Kilpatrick AM, Davies AJ, Hyatt AD, Daszak P (2009) Magnitude of the US trade in amphibians and presence of Batrachochytrium dendrobatidis and ranavirus infection in imported North American bullfrogs (Rana catesbeiana). Biol Conserv 142:1420-1426

Schock DM, Bollinger TK, Chinchar VG, Jancovich JK, Collins JP (2008) Experimental evidence that amphibian ranaviruses are multi-host pathogens. Copeia 2008: 133-143

Storfer A, Alfaro ME, Ridenhour BJ, Jancovich JK, Mech SG, Parris MJ, Collins JP (2007) Phylogenetic concordance analysis shows an emerging pathogen is novel and endemic. Ecol Lett 10:1075-1083

Stuart SN, Chanson JS, Cox NA, Young BE, Rodrigues ASL,

Editorial responsibility: Andrew Cunningham,

London, UK
Fischman DL, Waller RW (2004) Status and trends of amphibian declines and extinctions worldwide. Science 306:1783-1786

> Tweedell K, Granoff A (1968) Viruses and renal carcinoma of Rana pipiens. V. Effect of Frog Virus 3 on developing frog embryos and larvae. J Natl Cancer Inst 40:407-410

Wake DB, Vredenburg VT (2008) Are we in the midst of the sixth mass extinction? A view from the world of amphibians. Proc Natl Acad Sci USA 105:11466-11473

Williams T, Barbosa-Solomieu V, Chinchar GD (2005) A decade of advances in iridovirus research. Adv Virus Res 65:173-248

Yuan JS, Reed A, Chen F, Stewart CN Jr (2006) Statistical analysis of real-time PCR data. BMC Bioinformatics 7:85-97

Zar JH (2009) Biostatistical analysis, 5th edn Prentice Hall, Upper Saddle River, NJ

Zupanovic Z, Lopez G, Hyatt AD, Green B and others (1998) Giant toads Bufo marinus in Australia and Venezuela have antibodies against 'ranaviruses'. Dis Aquat Org 32:1-8

Submitted: June 22, 2009; Accepted: January 20, 2010

Proofs received from author(s): February 28, 2010 